\title{
Internal browning control in 'Laetitia' plums by modified atmosphere, management of ethylene and storage temperature
}

\author{
Josiane Costa Melo ${ }^{1}$, Cristiano André Steffens ${ }^{2}$, \\ Cassandro Vidal Talamini do Amarante ${ }^{2}$, Tiago Miqueloto ${ }^{3}$, Angélica Schmitz Heinzen ${ }^{4}$
}

Abstract - The objective of this study was to evaluate the effect of modified atmosphere (MA) and 1-methylcyclopropene (1-MCP) treatment on low storage temperature $\left(1.5^{\circ} \mathrm{C}\right)$ and $1-\mathrm{MCP}$ treatment on high storage temperature $\left(8.0^{\circ} \mathrm{C}\right)$ on fruit quality of 'Laetitia' plums, mainly on internal browning. The treatments evaluated were $1.5^{\circ} \mathrm{C} ; 1-\mathrm{MCP}\left(1.0 \mu \mathrm{L} \mathrm{L}^{-1}\right)+1.5^{\circ} \mathrm{C}$; MA + $1.5^{\circ} \mathrm{C} ; 1-\mathrm{MCP}+\mathrm{MA}+1.5^{\circ} \mathrm{C} ; 8.0^{\circ} \mathrm{C} ; 1-\mathrm{MCP}+8.0^{\circ} \mathrm{C}$. Fruit were stored for 30 and 40 days, followed by three day of shelf life. For fruit stored at $1.5^{\circ} \mathrm{C}$, the treatment with 1-MCP associated to MA provided higher flesh firmness, less intense skin red color and reduced occurrence of internal browning in comparison to the fruit stored at $1.5^{\circ} \mathrm{C}$ of the remaining treatments, for both periods of storage. In fruit not treated with $1-\mathrm{MCP}$ and stored at $8.0^{\circ} \mathrm{C}$ there was no occurrence of internal browning, despite of lower flesh firmness and more intense red color of the skin and flesh in comparison to the fruit stored at $1.5^{\circ} \mathrm{C}$. The treatment with $1-\mathrm{MCP}$ in fruit stored at 8.0 ${ }^{\circ} \mathrm{C}$ delayed those changes of flesh firmness and red color of the skin and flesh assessed after 30 days of storage, followed by three days of shelf life. The MA, regardless of 1-MCP treatment, had fruit with higher production of acetaldehyde after 30 days of storage, and ethanol after 30 and 40 days of storage at $1.5^{\circ} \mathrm{C}$. In fruit stored at $1.5^{\circ} \mathrm{C}$ without MA, the treatment with 1-MCP reduced the production of ethyl acetate, acetaldehyde and ethanol. Fruit stored at $8.0{ }^{\circ} \mathrm{C}$, regardless of 1-MCP treatment, had the lowest production of acetaldehyde and ethanol.

Index terms: Prunus salicina, 1-methylcyclopropene, chilling injury, postharvest.

\section{Controle do escurecimento da polpa em ameixas 'Laetitia' com a atmosfera modificada e o manejo do etileno e da temperatura de armazenamento}

Corresponding author: josycmello@hotmail.com

Received: October 15, 2020 Accepted: February 12, 2021

Copyright: All the contents of this journal, except where otherwise noted, is licensed under a Creative Commons Attribution License.

\section{$(\mathrm{cc}) \mathbf{\mathrm { EY }}$}

Resumo - O objetivo deste trabalho foi avaliar o efeito da atmosfera modificada (AM) e do tratamento com 1-MCP em baixa temperatura de armazenamento $\left(1,5^{\circ} \mathrm{C}\right)$ e do tratamento com 1 -MCP em elevada temperatura de armazenamento $\left(8,0^{\circ} \mathrm{C}\right)$ sobre a qualidade de ameixas 'Laetitia', especialmente sobre o escurecimento da polpa. Os tratamentos avaliados foram $1,5^{\circ} \mathrm{C}$; 1-MCP $\left(1,0 \mu \mathrm{L} \mathrm{L}^{-1}\right)+1,5^{\circ} \mathrm{C} ; 1,5^{\circ} \mathrm{C}+\mathrm{AM} ; 1-\mathrm{MCP}+1,5^{\circ} \mathrm{C}+\mathrm{AM} ; 8,0{ }^{\circ} \mathrm{C}$; e $1-\mathrm{MCP}+8,0^{\circ} \mathrm{C}$. Os frutos foram armazenados por 30 e 40 dias e após mantidos por mais três dias em condições ambiente. Na temperatura de $1,5^{\circ} \mathrm{C}, \mathrm{o} 1-\mathrm{MCP}$ associado à $\mathrm{AM}$ manteve maior firmeza de polpa e a coloração da casca menos avermelhada e reduziu o escurecimento de polpa, em relação aos demais tratamentos a $1,5^{\circ} \mathrm{C}$, em ambos os períodos de armazenamento. Em frutos não tratados com 1-MCP e armazenados na temperatura de $8,0^{\circ} \mathrm{C}$, não houve escurecimento de polpa, em ambos os períodos de armazenamento, porém os frutos apresentaram menor firmeza de polpa $\mathrm{e}$ a cor da casca e da polpa mais vermelha, em relação a temperatura de $1,5^{\circ} \mathrm{C}$. O uso de 1 -MCP em frutos armazenados a $8,0^{\circ} \mathrm{C}$ retardou essas alterações de firmeza de polpa e cor da casca e da polpa aos 30 dias de AR, seguidos por mais 3 dias em condições ambiente. A AM, independente da aplicação de 1-MCP, causou acúmulo de acetaldeído, aos 30 dias de armazenamento, e de etanol aos 30 e 40 dias de armazenamento a $1,5^{\circ} \mathrm{C}$. O uso de $1-\mathrm{MCP}$ a $1,5^{\circ} \mathrm{C}$ reduziu a produção de acetato de etila, acetaldeído e etanol sem AM. Fruto armazenados a $8,0^{\circ} \mathrm{C}$, independente da aplicação de 1-MCP, apresentaram menor acúmulo de acetaldeído e etanol.

Termos para indexação: Prunus salicina, 1-meticiclopropeno, dano por frio, pós-colheita.

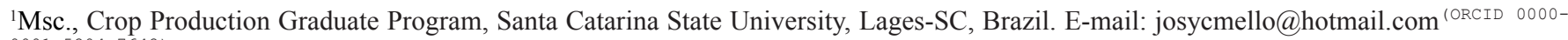
0001-5204-7642)

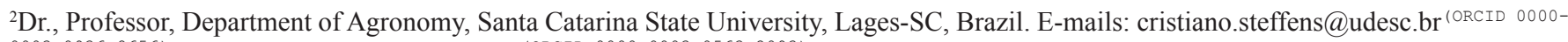
0003-0936-8656); cassandro.amarante@udesc.br (ORCID 0000-0003-0563-2093)

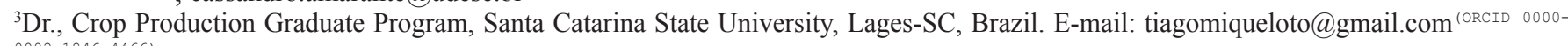
0002-1846-4466)

${ }^{4}$ Msc., Crop Production Graduate Program, Santa Catarina State University, Lages-SC, Brazil. E-mail: angelica_heinzen@hotmail.com(ORcid 0000-0003-2558-9336)
} 


\section{Introduction}

'Laetitia' plum tree is a cultivar that presents from medium to high demand of cold hours during the hibernal period, it is sensitive to scalding (Xylella fastidiosa) and tolerant to the bacteriosis (Xanthomonas arboricola pv. pruni) (DALBÓ et al., 2013). It produces quite attractive fruits, of medium to large size and ovoid format, with coloration of red-purple epidermis and yellow color pulp (FIORAVANÇO et al., 2015), which present climacteric pattern of respiration and production of ethylene and rapid change of texture after the harvest (ARGENTA et al., 2011).

The cold storage (CS) is the technology most used to extend the storage and marketing period of 'Laetitia' plums (STEFFENS et al., 2017). However, the CS of 'Laetitia' plums, in periods above 30 days, causes the internal browning (STEFFENS et al., 2014; STEFFENS et al., 2017). The intermal browning is a cold damage, caused by the storage in temperatures close to $0{ }^{\circ} \mathrm{C}$ (ARGENTA et al., 2011), due to an oxidative process that causes the peroxidation of lipids and the reduction in the efficiency of the antioxidant systems, occurring damage to the cellular membranes (SINGH;SINGH, 2013a; SINGH; SINGH, 2013b).

The use of technologies associated with the CS, which reduce the synthesis and the action of ethylene, such as modified atmosphere (MA), controlled atmosphere (CA), absorption of ethylene and the treatment with 1-methylciclopropene (1-MCP), although they do not fully inhibit the manifestation of the disorder, they have contributed to the reduction of the internal browning severity in 'Laetitia' plums (STANGER et al., 2017; STEFFENS et al., 2018). However, there is no information on the combined effect of the MA and the 1-MCP on the maturation and control of internal browning in 'Laetitia' plums.

As the internal browning is a cold damage, higher storage temperatures $\left(8\right.$ to $\left.10^{\circ} \mathrm{C}\right)$ reduce the internal browning, causing rapid ripening, with rapid loss of fruit consistency and evolution of the peel color, reducing the storage duration. The 1-MCP inhibits the softening and the evolution of the peel color of 'Laetitia' plums (STEFFENS et al., 2018), becoming a potential post-harvest strategy for the storage in temperatures higher than the recommended for plum $\left(0\right.$ to $\left.1.5^{\circ} \mathrm{C}\right)$, avoiding the harm by cold and reducing the energy consumption (MINAS et al., 2013).

The objective of this study was to evaluate the effect of MA and the treatment with 1-MCP in low storage temperature $\left(1.5^{\circ} \mathrm{C}\right)$, and the treatment with 1 -MCP in high storage temperature $\left(8.0^{\circ} \mathrm{C}\right)$, on the quality of 'Laetitia' plums, especially on internal browning.

\section{Material and Methods}

'Laetitia' plums were harvested in a 15 years old commercial orchard, located in the municipality of Lages, Santa Catarina (27 $77^{\prime} 78^{\prime \prime}$ S and 50 21'19' W), in maturation stage where the fruits presented between 40 to $50 \%$ of the epidermis covered with red coloration, in the harvest 2018/2019. Fruits that presented the color characteristics cited were harvested, using for these 100 plants of the orchard. After the harvest, the fruits were transported to the laboratory, those with defects (rotten, with lesion and dissonant dimensions) were eliminated, and the others were homogenized for composition of the samples. Four samples of 20 fruits were used for the analysis of the flesh firmness, titratable acidity (TA), soluble solids (SS) and peel color $\left(h^{\circ}\right)$ in the most and the less red regions of the fruit.

The treatments evaluated were: storage at $1.5^{\circ} \mathrm{C}$; 1-MCP $\left(1.0 \mu \mathrm{L} \mathrm{L}^{-1}\right)+$ storage at $1.5{ }^{\circ} \mathrm{C}$; storage at 1.5 ${ }^{\circ} \mathrm{C}$ in MA; $1-\mathrm{MCP}+$ storage at $1.5^{\circ} \mathrm{C}$ in MA; storage at $8.0{ }^{\circ} \mathrm{C}$; and $1-\mathrm{MCP}+$ storage at $8.0^{\circ} \mathrm{C}$. The experiment was conducted in entirely randomized design, with four replications and experimental units composed of 25 fruits.

For the application of 1-MCP $\left(1.0 \mu \mathrm{L} \mathrm{L}^{-1}\right)$ the fruits were placed in a hermetic container (microchamber of $180 \mathrm{~L}$ ), in the temperature of $20 \pm 2^{\circ} \mathrm{C}$ and $\mathrm{RH}$ of $60 \pm 5 \%$. In the interior of the microchamber, it was added the SmartFresh ${ }^{\circledR}$ product $(0.14 \%$ of 1 -MCP in powder formulation), where the fruits were exposed for 24 hours. During the application period of the 1-MCP, the fruits of the other treatments that did not receive the product application were in ambient condition. After the application of the 1-MCP, the fruits of all treatments were stored in cold chambers, in the respective storage temperatures previously defined in the treatments. The storage temperature was monitored daily with mercury bulb thermometers introduced in the flesh of the fruits.

In the treatments submitted to MA, it was used low density polyethylene film $(40 \mu \mathrm{m})$ to conditioning the fruits, where sachets were also placed containing hydrated lime ( $50 \mathrm{~g} \mathrm{~kg}^{-1}$ of fruit), to absorb the $\mathrm{CO}_{2}$ produced by the fruits' breathing. During the storage, the partial pressures of $\mathrm{O}_{2}$ and $\mathrm{CO}_{2}$ in the package interior were monitored weekly with the aid of a gas analyzer (Schelle ${ }^{\circledR}$, Germany). The package after the storage were opened.

After 30 and 40 days of storage, followed by three more days in ambient conditions $\left(20 \pm 2{ }^{\circ} \mathrm{C}\right.$ and $\mathrm{RH}$ of $60 \pm 5 \%$ ), the fruits were evaluated as to the red color index (RCI), epidermis color (hue angle; $h^{\circ}$ ) in the most and the less red regions of the fruit, TA, SS, flesh firmness, flesh browning index and incidence, and color attributes (brightness $-L-$ and $h^{\circ}$ ). 
The red color index was determined by evaluating the surface of the fruits covered with red coloration, being attributed notes from 1 to $4(1,2,3$ and 4 to $0-25 \%$, $26-50 \%, 51-75 \%$ and $76-100 \%$ of the fruit surface red pigmented, respectively). The index was calculated by the sum of the products of the fruit number by the respective level, divided by the sample fruits total.

The determination of the epidermis color (hue angle; $h^{\circ}$ ) of the most and the less red portions of the epidermis and the pulp was performed with Konica Minolta $^{\circledR}$, model CR 400 (Osaka, Japan). The $h^{\circ}$ defines the basic coloration, in which $0^{\circ}=\mathrm{red}, 90^{\circ}=$ yellow and $180^{\circ}=$ green.

The TA values (meq $100 \mathrm{~mL}^{-1}$ ) were obtained in a sample of $10 \mathrm{~mL}$ of juice, of transversal slices, removed from the equatorial region of the fruits submitted to extraction in a centrifuge. The sample obtained was diluted in $90 \mathrm{~mL}$ of distilled water and titrated with $\mathrm{NaOH} 0.1$ $\mathrm{N}$ solution until $\mathrm{pH}$ 8.1. The contents of SS $\left({ }^{\circ} \mathrm{Brix}\right)$ were determined by refractometry, using the extracted juice, as described for the TA, and the temperature effect correction $\left(20^{\circ} \mathrm{C}\right)$ performed.

The flesh firmness was quantified using an electronic penetrometer model GS-14 (Güzz ${ }^{\circledR}$ Manufacturing Pty Ltd, Strand, South Africa), equipped with a tip of $8 \mathrm{~mm}$ in diameter, having the penetration depth of $9 \mathrm{~mm}$.

The incidence $(\%)$ of internal browning was analyzed through the count of the fruits that presented the disorder, observed after a longitudinal cut, regarding the sample fruits total. The internal browning index was evaluated according to levels 1 to 4 , and attributing level 0 for fruits without internal browning, level 2 for fruits that present up to $10 \%$ of internal browning, level 3 for fruits with 11 up to $30 \%$ of internal browning and level 4 for fruits with more than $30 \%$ of internal browning. The color attributes of the flesh (brightness $-L-$ and $h^{\circ}$ ) were determined with Konica Minolta ${ }^{\circledR}$ colorimeter; model CR 400 (Osaka, Japan). Readings were performed in four distinct regions of the flesh after cross-cutting of the fruit, in the equatorial region.

The data were submitted to the variance analysis (ANOVA) and the averages of the treatments compared by the LSD test $(p<0.05)$. The incidence data of the internal browning were transformed to arcsine $[(\mathrm{x}+0.5) / 100]^{1 / 2}$, prior to the ANOVA.

\section{Results and discussion}

In the harvest, the fruits presented flesh firmness of $75.5 \mathrm{~N}, \mathrm{TA}$ of $1.62 \%$ of malic acid, SS of $10.8^{\circ} \mathrm{Brix}$ and peel $h^{\circ}$ in the most and the least red regions of the fruit of 65.3 and 82.4 , respectively.

The fruits stored in MA $\left(1.5^{\circ} \mathrm{C}+\mathrm{MA}\right.$ and 1-MCP $+1.5^{\circ} \mathrm{C}+\mathrm{MA}$ ) became exposed to conditions of $\mathrm{O}_{2}+$ $\mathrm{CO}_{2}$ average of $1.3 \mathrm{kPa}+0.8 \mathrm{kPa}$ and $1.0 \mathrm{kPa}+0.9 \mathrm{kPa}$, for 30 and 40 days of storage, respectively. These average atmospheric conditions are close to those considered as ideal $\left(1 \mathrm{kPa} \mathrm{O}+1 \mathrm{kPa} \mathrm{CO}_{2}\right)$ for plums storage (STEFFENS et al., 2014). However, the partial pressure of $\mathrm{O}_{2}$ varied, in most of the storage, from 0.65 to 1.08 $\mathrm{kPa}$ (during 23 days) for fruits stored for 30 days, and from 0.16 to $0.42 \mathrm{kPa}$ (for 33 days) for fruits stored for 40 days. In addition, in the last two weeks of storage, the fruits became exposed to partial pressures of $\mathrm{CO}_{2}$ ranging from 1.6 to $2.1 \mathrm{kPa}$ and 0.9 to $5.5 \mathrm{kPa}$, for 30 and 40 days of storage, respectively. Although sachets containing hydrated lime were placed within the package to absorb the $\mathrm{CO}_{2}$ produced by the respiratory activity of the fruit, the partial pressure of $\mathrm{CO}_{2}$ was above the considered ideal $(1 \mathrm{kPa})$ for conditions with lower $\mathrm{O}_{2}(\leq 1 \mathrm{kPa})$ (STEFFENS et al., 2014). Possibly, saturation of the hydrated lime with $\mathrm{CO}_{2}$ occurred, reducing the ability to absorb it, causing its accumulation in the package interior. The fruits of the other treatments, due to only the refrigerated environment, became exposed to the air atmosphere $\left(21.0 \mathrm{kPa}\right.$ of $\mathrm{O}_{2}+$ $0.04 \mathrm{kPa}$ of $\mathrm{CO}_{2}$ ).

The RCI was lower in plums submitted to the conditions of $1-\mathrm{MCP}+1.5^{\circ} \mathrm{C}+\mathrm{MA}$ and $1-\mathrm{MCP}+1.5^{\circ} \mathrm{C}$ after 30 days of storage plus 3 days of the fruits exposure in environmental conditions. After 40 days of storage and 3 days in ambient conditions, the lowest RCI values were observed in the condition of $1.5^{\circ} \mathrm{C}+\mathrm{MA}$ and 1-MCP + $1.5^{\circ} \mathrm{C}+\mathrm{MA}$ (Table 1). The treatment with 1-MCP also delayed the development of the red color in 'Blackamber' and 'Red Lane' plums (MINAS et al., 2013) and in 'Maria Aurelia' nectarines (ÖZHAYA et al., 2016). Regarding the effect of MA in the storage at $1.5^{\circ} \mathrm{C}$, the low partial pressure of $\mathrm{O}_{2}$ by reducing the metabolism of the fruits, explains the lowest RCI observed. 
Table 1. Red color index and peel color $\left(h^{\circ}\right)$ in the most and the least red regions of 'Laetitia' plums stored in different conditions for 30 and 40 days, followed by three days of exposure in ambient condition $\left(20 \pm 2{ }^{\circ} \mathrm{C} / 60 \pm 5 \%\right.$ of $\left.\mathrm{RH}\right)$.

\begin{tabular}{lcccccc} 
& \multicolumn{3}{l}{ Red color index $(\mathrm{RCI})$} & \multicolumn{2}{l}{$h^{\circ}$ in the least red region } & \multicolumn{2}{c}{$h^{\circ}$ in the most red region } \\
\cline { 2 - 7 } & 30 days & 40 days & 30 days & 40 days & 30 days & 40 days \\
\hline $1.5^{\circ} \mathrm{C}$ & $3.6 \mathrm{~b}$ & $4.0 \mathrm{a}$ & $29.1 \mathrm{c}$ & $36.9 \mathrm{c}$ & $19.8 \mathrm{c}$ & $21.3 \mathrm{~b}$ \\
$1-\mathrm{MCP}+1.5^{\circ} \mathrm{C}$ & $3.2 \mathrm{c}$ & $3.8 \mathrm{ab}$ & $47.1 \mathrm{~b}$ & $50.5 \mathrm{~b}$ & $23.4 \mathrm{~b}$ & $22.5 \mathrm{~b}$ \\
$1.5^{\circ} \mathrm{C}+\mathrm{MA}$ & $3.7 \mathrm{~b}$ & $3.3 \mathrm{c}$ & $53.0 \mathrm{a}$ & $53.6 \mathrm{~b}$ & $23.5 \mathrm{~b}$ & $23.2 \mathrm{~b}$ \\
$1-\mathrm{MCP}+1.5^{\circ} \mathrm{C}+\mathrm{MA}$ & $3.4 \mathrm{cb}$ & $3.6 \mathrm{~b}$ & $52.5 \mathrm{ab}$ & $60.9 \mathrm{a}$ & $25.3 \mathrm{a}$ & $26.2 \mathrm{a}$ \\
$8.0^{\circ} \mathrm{C}$ & $4.0 \mathrm{a}$ & $4.0 \mathrm{a}$ & $15.7 \mathrm{e}$ & $13.7 \mathrm{e}$ & $13.2 \mathrm{e}$ & $13.7 \mathrm{c}$ \\
$1-\mathrm{MCP}+8.0^{\circ} \mathrm{C}$ & $4.0 \mathrm{a}$ & $4.0 \mathrm{a}$ & $23.2 \mathrm{~d}$ & $22.0 \mathrm{~d}$ & $15.8 \mathrm{c}$ & $14.0 \mathrm{c}$ \\
$\mathrm{CV}(\%)$ & 6.7 & 4.0 & 6.0 & 9.2 & 10.6 & 7.5 \\
\hline
\end{tabular}

Average followed by distinct letters, in the columns, differ among themselves by the LSD test $(p<0.05)$.

In the temperature of $8.0^{\circ} \mathrm{C}$ the fruits presented, in both storage periods, totally red, even with the application of 1-MCP (Table 1). This result evidences that in this storage temperature the 1-MCP did not present efficiency on this quality attribute.

In general, after 30 days of storage plus three days in ambient conditions, the least intense red color, in the most red portion of the fruit, was registered in the treatment $1-\mathrm{MCP}+1.5^{\circ} \mathrm{C}+\mathrm{MA}$. In the least red portion of the fruit, higher $h^{\circ}$ value was observed in fruits of the treatments $1.5^{\circ} \mathrm{C}+\mathrm{MA}$ and $1-\mathrm{MCP}+1.5^{\circ} \mathrm{C}+\mathrm{MA}$. The lowest $h^{\circ}$ value of the peel (most intense red color), both in the most and the least red regions of the fruit, was observed in fruits stored at $8.0^{\circ} \mathrm{C}$. In this temperature, the fruits treated with 1-MCP presented higher $h^{\circ}$ value than the untreated fruits. After 40 days of storage plus three days in ambient conditions, the fruits of treatment 1-MCP $+1.5^{\circ} \mathrm{C}+$ MA presented higher $h^{\circ}$ value in the most and the least red portions of the fruit. In this storage time, in the temperature of $8.0^{\circ} \mathrm{C}$, the $1-\mathrm{MCP}$ only delayed the evolution of the peel color in the least red region of the fruit (Table 1). The lowest evolution of the epidermis coloration in 'Laetitia' plums treated with $1-\mathrm{MCP}$ is related, in part, to the lowest ethylene production rate, because the change in the color, during plums maturation, is a process dependent on the action of this phytohormone (STANGER et al., 2017). In addition to the 1-MCP, the use of MA has also been shown to be an efficient tool to delay the coloration change process of the fruit epidermis, as reported by Selcuk and Erkan (2014).

The plums of treatment $1-\mathrm{MCP}+1.5{ }^{\circ} \mathrm{C}+\mathrm{MA}$ presented higher pulp firmness after the periods of 30 and 40 days of storage, followed by three more days in ambient conditions, indicating that 1-MCP, associated with the effects of low $\mathrm{O}_{2}$ of the MA, delays the loss of fruit consistency. In the temperature of $8.0{ }^{\circ} \mathrm{C}$, the 1-MCP maintained higher pulp firmness than untreated fruits only after 30 days of storage plus three days in ambient conditions (Table 2). The effect of the 1-MCP in the maintenance of this attribute is associated with the reduction of the activity of pectolytic enzymes, due to the reduction of the ethylene action in the fruit (ÖZHAYA et al., 2016). Khan and Singh (2008) also reported higher flesh firmness in 'Tegan Blue' plums treated with 1-MCP and stored in MA.

The TA, after 30 days of storage followed by 3 more days in ambient conditions, was higher in fruits of the treatments $1-\mathrm{MCP}+1.5^{\circ} \mathrm{C}, 1-\mathrm{MCP}+1.5{ }^{\circ} \mathrm{C}+\mathrm{MA}$ and $1-\mathrm{MCP}+8.0^{\circ} \mathrm{C}$, while after 40 days followed by three more days in ambient conditions, the highest value was in the treatment $1-\mathrm{MCP}+1.5^{\circ} \mathrm{C}+\mathrm{MA}$. In both evaluations, the 1-MCP in fruits stored at $8.0^{\circ} \mathrm{C}$ maintained higher TA than in untreated fruits (Table 2). Steffens et al. (2013) also observed higher TA values in 'Laetitia' plums treated with 1-MCP. The effect of the 1-MCP on the maintenance of the TA of the fruits can be related to the lower consumption of the acids in the cycle of the tricarboxylic acids, by the reduction in the respiratory activity (ALVES et al., 2009).

The lowest SS, after 30 and 40 days of storage followed by three days in ambient conditions, was observed in the fruits stored in temperature of $8.0^{\circ} \mathrm{C}$, independent of the treatment with 1-MCP (Table 2). This result can be considered expected, the storage at higher temperatures maintains the metabolism more accelerated than in lower temperatures, occurring higher consumption of sugars, which are the main respiratory substrates. However, it was expected that the 1-MCP would reduce the process at higher temperatures, which was not observed. It is possible that in higher storage temperature occurred a rapid synthesis of new ethylene receptors making the fruit again responsive to the phytohormone, which annulled the effect of the 1-MCP in reducing the fruit metabolism in storage temperature of $8.0^{\circ} \mathrm{C}$.

In general, the highest values for the SS/TA ratio were observed in the treatments of $1.5^{\circ} \mathrm{C}$ and $1.5^{\circ} \mathrm{C}+$ MA, and the lowest in the treatments $1-\mathrm{MCP}+1.5^{\circ} \mathrm{C}+$ $\mathrm{MA}$ and 1-MCP $+8.0^{\circ} \mathrm{C}$, in both storage times (Table 2). The TA determined these results, because the treatments that provided lower TA presented higher SS/TA ratio. The maintenance of the TA is important to ensure the balance with the sugar contents (NUNES et al., 2019). 
The ethyl acetate was higher in plums of treatments $1.5^{\circ} \mathrm{C}$ and $1.5^{\circ} \mathrm{C}+\mathrm{MA}$, after 30 and 40 days of storage, respectively (Table 3 ). The highest concentrations of acetaldehyde and ethanol were found in fruits of the treatment $1.5^{\circ} \mathrm{C}+\mathrm{MA}$, independently of the evaluation moment (Table 3 ), possibly due to the intense reduction of the partial pressure of $\mathrm{O}_{2}$, especially in the final period of the storage, as described previously. Lumpkin et al. (2014) reported higher production of products of the fermentative metabolism with the decrease of the $\mathrm{O}_{2}$ in 'Scarlett Spur Red Delicious' apples. The lowest availability of $\mathrm{O}_{2}$ induces alternative routes for the production of ATP, such as fermentation (BAILEY-SERRES et al., 2012), forming compounds that, in high concentrations, result in fermentative odors (off-flavors) (WRIGHT et al., 2015; FORNEY, 2016).

Table 2. Flesh firmness, soluble solids (SS), titratable acidity (TA) and SS/TA ratio in 'Laetitia' plum stored in different conditions for 30 and 40 days, followed by three days in ambient condition $\left(20 \pm 2{ }^{\circ} \mathrm{C} / 60 \pm 5 \%\right.$ of RU).

\begin{tabular}{|c|c|c|c|c|}
\hline Treatment & $\begin{array}{l}\text { Flesh firmness } \\
\text { (N) }\end{array}$ & $\begin{array}{c}\mathrm{SS} \\
\left({ }^{\circ} \mathrm{Brix}\right)\end{array}$ & $\begin{array}{c}\text { TA } \\
(\% \text { malic acid })\end{array}$ & $\begin{array}{l}\text { SS/TA } \\
\text { Ratio }\end{array}$ \\
\hline & \multicolumn{4}{|c|}{30 days } \\
\hline $1.5^{\circ} \mathrm{C}$ & $11.2 \mathrm{c}$ & $11.2 \mathrm{a}$ & $0.99 \mathrm{~b}$ & $11.3 \mathrm{a}$ \\
\hline $1-\mathrm{MCP}+1.5^{\circ} \mathrm{C}$ & $16.1 \mathrm{~b}$ & $11.1 \mathrm{a}$ & $1.19 \mathrm{a}$ & $9.4 \mathrm{~b}$ \\
\hline $1.5^{\circ} \mathrm{C}+\mathrm{MA}$ & $10.8 \mathrm{c}$ & $10.1 \mathrm{~b}$ & $0.97 \mathrm{~b}$ & $10.4 \mathrm{ab}$ \\
\hline $1-\mathrm{MCP}+1.5^{\circ} \mathrm{C}+\mathrm{MA}$ & $18.8 \mathrm{a}$ & $10.4 \mathrm{~b}$ & $1.28 \mathrm{a}$ & $8.1 \mathrm{c}$ \\
\hline $8.0^{\circ} \mathrm{C}$ & $6.4 \mathrm{e}$ & $9.5 \mathrm{c}$ & $0.97 \mathrm{~b}$ & $9.8 \mathrm{~b}$ \\
\hline $1-\mathrm{MCP}+8.0^{\circ} \mathrm{C}$ & $8.2 \mathrm{~d}$ & $9.7 \mathrm{c}$ & $1.22 \mathrm{a}$ & $8.0 \mathrm{c}$ \\
\hline \multirow[t]{2}{*}{$\mathrm{CV}(\%)$} & 6.4 & 2.88 & 8.36 & 8.2 \\
\hline & \multicolumn{4}{|c|}{40 days } \\
\hline $1.5^{\circ} \mathrm{C}$ & $11.8 \mathrm{c}$ & $11.0 \mathrm{a}$ & $0.70 \mathrm{~d}$ & $15.7 \mathrm{a}$ \\
\hline $1-\mathrm{MCP}+1.5^{\circ} \mathrm{C}$ & $18.6 \mathrm{~b}$ & $10.4 \mathrm{ab}$ & $0.99 \mathrm{~b}$ & $10.5 \mathrm{cb}$ \\
\hline $1.5^{\circ} \mathrm{C}+\mathrm{MA}$ & $12.2 \mathrm{c}$ & $10.4 \mathrm{ab}$ & $0.65 \mathrm{~d}$ & $16.0 \mathrm{a}$ \\
\hline $1-\mathrm{MCP}+1.5^{\circ} \mathrm{C}+\mathrm{MA}$ & $24.0 \mathrm{a}$ & $10.4 \mathrm{ab}$ & $1.17 \mathrm{a}$ & $8.9 \mathrm{~d}$ \\
\hline $8.0^{\circ} \mathrm{C}$ & $6.4 \mathrm{~d}$ & $10.1 \mathrm{c}$ & $0.87 \mathrm{c}$ & $11.6 \mathrm{~b}$ \\
\hline $1-\mathrm{MCP}+8.0^{\circ} \mathrm{C}$ & $7.8 \mathrm{~d}$ & $10.2 \mathrm{c}$ & $1.05 \mathrm{~b}$ & $9.7 \mathrm{~cd}$ \\
\hline $\mathrm{CV}(\%)$ & 6.9 & 5.1 & 6.85 & 7.4 \\
\hline
\end{tabular}

Average followed by distinct letters, in the columns, differ among themselves by the LSD test $(p<0.05)$.

Table 3. Concentrations of ethyl acetate, acetaldehyde and ethanol in 'Laetitia' plums stored in different conditions for 30 and 40 days, followed by three days in ambient condition $\left(20 \pm 2^{\circ} \mathrm{C} / 60 \pm 5 \%\right.$ of $\left.\mathrm{RH}\right)$.

\begin{tabular}{lccc}
\hline Treatment & $\begin{array}{c}\text { Ethyl acetate } \\
\left(\mu \mathrm{L} \mathrm{L}^{-1}\right)\end{array}$ & $\begin{array}{c}\text { Acetaldehyde } \\
\left(\mu \mathrm{L} \mathrm{L}^{-1}\right)\end{array}$ & $\begin{array}{c}\text { Ethanol } \\
\left(\mu \mathrm{L} \mathrm{L}^{-1}\right)\end{array}$ \\
\hline $1.5^{\circ} \mathrm{C}$ & $3.5 \mathrm{a}$ & 30 days & $80.8 \mathrm{~b}$ \\
$1-\mathrm{MCP}+1.5^{\circ} \mathrm{C}$ & $2.5 \mathrm{~b}$ & $0.12 \mathrm{~b}$ & $9.3 \mathrm{~b}$ \\
$1.5^{\circ} \mathrm{C}+\mathrm{MA}$ & $2.5 \mathrm{~b}$ & $0.04 \mathrm{c}$ & $299.9 \mathrm{a}$ \\
$1-\mathrm{MCP}+1.5^{\circ} \mathrm{C}+\mathrm{MA}$ & $1.5 \mathrm{c}$ & $0.20 \mathrm{a}$ & $66.0 \mathrm{~b}$ \\
$8.0^{\circ} \mathrm{C}$ & $1.9 \mathrm{cb}$ & $0.06 \mathrm{cb}$ & $16.4 \mathrm{~b}$ \\
$1-\mathrm{MCP}+8.0^{\circ} \mathrm{C}$ & $1.7 \mathrm{c}$ & $0.08 \mathrm{cb}$ & $8.5 \mathrm{~b}$ \\
$\mathrm{CV}(\%)$ & 22.1 & $0.05 \mathrm{c}$ & 75.0 \\
\hline & & 44.1 & $168.2 \mathrm{cb}$ \\
$1.5^{\circ} \mathrm{C}$ & $4.4 \mathrm{~b}$ & $40 \mathrm{days}$ & $41.1 \mathrm{c}$ \\
$1-\mathrm{MCP}+1.5^{\circ} \mathrm{C}$ & $1.3 \mathrm{c}$ & $0.24 \mathrm{ab}$ & $785.0 \mathrm{a}$ \\
$1.5^{\circ} \mathrm{C}+\mathrm{MA}$ & $6.2 \mathrm{a}$ & $0.09 \mathrm{~d}$ & $332.3 \mathrm{~b}$ \\
$1-\mathrm{MCP}+1.5^{\circ} \mathrm{C}+\mathrm{MA}$ & $4.3 \mathrm{~b}$ & $0.28 \mathrm{a}$ & $35.2 \mathrm{c}$ \\
$8.0^{\circ} \mathrm{C}$ & $2.2 \mathrm{c}$ & $0.16 \mathrm{c}$ & $21.5 \mathrm{c}$ \\
$1-\mathrm{MCP}+8.0^{\circ} \mathrm{C}$ & $1.5 \mathrm{c}$ & $0.21 \mathrm{bc}$ & 81.1 \\
$\mathrm{CV}(\%)$ & 26.3 & $0.22 \mathrm{~b}$ & 18.5 \\
\hline
\end{tabular}

Average followed by distinct letters, in the columns, differ among themselves by the LSD test $(p<0.05)$. 
After 30 and 40 days of storage, followed by three more days in ambient conditions, there was no incidence of internal browning in plums submitted to the conditions of $8.0^{\circ} \mathrm{C}$ and $1-\mathrm{MCP}+8.0^{\circ} \mathrm{C}$, but the disorder was observed in all treatments at $1.5^{\circ} \mathrm{C}$. After 30 days of storage plus three days in ambient conditions, the internal browning index was higher in fruits stored at $1.5^{\circ} \mathrm{C}$ in MA, without differing from the fruits of the other treatments at 1.5 ${ }^{\circ} \mathrm{C}$. At the 40 days of storage plus three days in ambient conditions, the highest pulp browning index was observed in the fruits of the treatment $1.5^{\circ} \mathrm{C}+\mathrm{MA}$ (all the fruits presented the disorder), followed by the treatments 1.5 ${ }^{\circ} \mathrm{C}, 1-\mathrm{MCP}+1.5^{\circ} \mathrm{C}+\mathrm{MA}$ and $1-\mathrm{MCP}+1.5^{\circ} \mathrm{C}$ (Table 4).

The internal browning is due to the production of reactive oxygen species, which cause the peroxidation of lipids, and the reduction in the efficiency of the antioxidant systems, with consequent damage to the cellular membranes (SINGH; SINGH, 2013a; 2013b). Although it is a damage caused by the low storage temperature, the manifestation of internal browning can be aggravated by the ethylene (ARGENTA et al., 2011; ALVES et al., 2009; CORRÊA et al., 2011; STEFFENS et al., 2013). In addition, inadequate storage conditions, such as very low $\mathrm{O}_{2}$, observed in the treatments in MA, can also intensify the manifestation of the disorder (STEFFENS et al., 2017). The highest internal browning in 'Laetitia' plums in MA, regarding to fruits stored in CS, was also observed by Steffens et al. (2009), due to the accumulation of $\mathrm{CO}_{2}$ in the package interior. In the present study, $\mathrm{CO}_{2}$ absorber (hydrated lime) was added in the package interior, but in the last two weeks of storage there was accumulation of the gas in the package interior, notably in the last storage week for 40 days. In addition, during the last 33 days of storage, the partial pressure of average $\mathrm{O}_{2}$, in the package interior, remained in $0.36 \mathrm{kPa}$, which can induce the fruits anaerobic respiration. This can be verified by the high accumulation of products of the fruit fermentative metabolism in the MA.
The fruits stored at $8.0^{\circ} \mathrm{C}$, in both storage periods, presented the lowest internal browning values (Table 4). Minas et al. (2013) also observed this result in plums. The authors state that the plums storage in higher temperatures $\left(10^{\circ} \mathrm{C}\right)$, in association with the $1-\mathrm{MCP}$, is a potential alternative to delay the fruits maturation and avoid the internal browning.

The storage at $8.0{ }^{\circ} \mathrm{C}$, even with the use of the 1-MCP, presented, at the end of the storage, three more days in ambient conditions, advanced maturation (reduced flesh firmness values and SS, and higher evolution of the red color in the peel), as well as reddish of the flesh (reduced values of $L$ and $h^{\circ}$ ), due to the migration of peel pigments to the flesh, especially at the 40 days of storage plus three days in ambient conditions (Table 5). Reduced $L$ and $h^{\circ}$ values can occur in function of high internal browning, such as in the treatment in MA, and by the reddish of the internal resulting from the advanced maturation stage, as in the fruits stored at $8.0^{\circ} \mathrm{C}$, with or without application of 1-MCP.

Table 4. Incidence and internal browning index in 'Laetitia' plums stored in different conditions for 30 and 40 days, followed by three days in ambient condition $\left(20 \pm 2{ }^{\circ} \mathrm{C} / 60 \pm 5 \%\right.$ of $\left.\mathrm{RH}\right)$.

\begin{tabular}{lcccc}
\hline \multirow{2}{*}{ Treatment } & \multicolumn{4}{c}{ Intrenal browning } \\
\cline { 2 - 5 } & \multicolumn{3}{c}{ Incidence $(\%)$} & \multicolumn{3}{c}{ Index(1-4) } \\
\cline { 2 - 5 } $1.5^{\circ} \mathrm{C}$ & 20 days & 40 days & 30 days & 40 days \\
$1-\mathrm{MCP}+1.5^{\circ} \mathrm{C}$ & $25.1 \mathrm{ab}$ & $37.8 \mathrm{~b}$ & $1.3 \mathrm{ab}$ & $1.4 \mathrm{~b}$ \\
$1.5^{\circ} \mathrm{C}+\mathrm{MA}$ & $44.8 \mathrm{a}$ & $22.3 \mathrm{cb}$ & $1.2 \mathrm{ab}$ & $1.2 \mathrm{cb}$ \\
$1-\mathrm{MCP}+1.5^{\circ} \mathrm{C}+\mathrm{MA}$ & $6.5 \mathrm{ab}$ & $32.9 \mathrm{cb}$ & $1.7 \mathrm{a}$ & $3.4 \mathrm{a}$ \\
$8.0^{\circ} \mathrm{C}$ & $0.0 \mathrm{~b}$ & $0.0 \mathrm{c}$ & $1.3 \mathrm{ab}$ & $1.3 \mathrm{cb}$ \\
$1-\mathrm{MCP}+8.0^{\circ} \mathrm{C}$ & $0.0 \mathrm{~b}$ & $0.0 \mathrm{c}$ & $1.0 \mathrm{~b}$ & $1.0 \mathrm{c}$ \\
$\mathrm{CV}(\%)$ & 23.9 & 16.3 & 23.9 & 16.3 \\
\hline
\end{tabular}

Average followed by distinct letters, in the columns, differ among themselves by the LSD test $(p<0.05)$. 
Table 5. Flesh color attribute $\left(L\right.$ and $\left.h^{\circ}\right)$ in 'Laetitia' plums stored in different conditions for 30 and 40 days, followed by three days in ambient condition $\left(20 \pm 2{ }^{\circ} \mathrm{C} / 60 \pm 5 \%\right.$ of $\left.\mathrm{RH}\right)$

\begin{tabular}{lcccc}
\hline & \multicolumn{3}{c}{$L$} & \multicolumn{2}{c}{$h^{\circ}$} \\
\cline { 2 - 5 } Treatments & 30 days & 40 days & 30 days & 40 days \\
\hline $1.5^{\circ} \mathrm{C}$ & $52.14 \mathrm{c}$ & $50.04 \mathrm{~b}$ & $82.98 \mathrm{~d}$ & $81.15 \mathrm{a}$ \\
$1-\mathrm{MCP}+1.5^{\circ} \mathrm{C}$ & $53.97 \mathrm{~b}$ & $52.50 \mathrm{~b}$ & $86.61 \mathrm{c}$ & $85.14 \mathrm{a}$ \\
$1.5^{\circ} \mathrm{C}+\mathrm{MA}$ & $53.50 \mathrm{cb}$ & $41.11 \mathrm{~d}$ & $85.94 \mathrm{c}$ & $79.34 \mathrm{ab}$ \\
$1-\mathrm{MCP}+1.5^{\circ} \mathrm{C}+\mathrm{MA}$ & $57.06 \mathrm{a}$ & $56.14 \mathrm{a}$ & $90.29 \mathrm{a}$ & $86.93 \mathrm{a}$ \\
$8.0^{\circ} \mathrm{C}$ & $50.56 \mathrm{~d}$ & $47.27 \mathrm{c}$ & $85.94 \mathrm{c}$ & $74.73 \mathrm{~b}$ \\
$1-\mathrm{MCP}+8.0^{\circ} \mathrm{C}$ & $50.64 \mathrm{~d}$ & $45.52 \mathrm{c}$ & $88.13 \mathrm{~b}$ & $71.43 \mathrm{~b}$ \\
$\mathrm{CV}(\%)$ & 1.56 & 3.74 & 0.59 & 5.41 \\
\hline
\end{tabular}

Average followed by distinct letters, in the columns, differ among themselves by the LSD test $(p<0.05)$.

Although at $8.0^{\circ} \mathrm{C}$ did not occur the development of the internal browning, there was high quality loss of the fruits. It was believed that the effect of the 1-MCP preventing the action of the ethylene could compensate, at least in part, the elevation of the temperature on the control of the ripening of 'Laetitia', as observed in other plum cultivars (MINAS et al., 2013). Although this did not occur in a substantial way in the present study, perhaps the reapplication of 1-MCP, in different moments of the storage at $8.0^{\circ} \mathrm{C}$, can have higher effect on the ripening control and therefore allow obtaining fruits without internal browning and with better maintenance of the quality, and with lower energy consumption for the fruits' cooling.

\section{Conclusions}

The best general quality of 'Laetitia' plums was obtained with the application of 1-MCP and the storage at $1.5^{\circ} \mathrm{C}$ in $\mathrm{MA}$, because it reduced the internal browning and delayed the ripening. In storage temperature at $8.0^{\circ} \mathrm{C}$, with or without application of 1-MCP, the fruits did not present internal browning, but presented rapid ripening.

\section{Acknowledgments}

The authors thank the National Council for Scientific and Technological Development (CNPq), the Research Support Program of the Santa Catarina State University (PAP-UDESC), the Foundation for Research and Innovation of the State of Santa Catarina (FAPESC), as well as the Coordination of Higher Education Personnel Training (CAPES) for the financial support of this project and for the fellowships granted.

\section{References}

ALVES, E.O.; STEFFENS, C.A.; AMARANTE, C.V.T.; PAVANELLO, E.P.P.; BRACKMANN. Manejo do etileno durante o armazenamento de ameixas 'Laetitia' em atmosfera controlada. Ciência Rural, Santa Maria, v.39, n.9, p.445-451, 2009.

ARGENTA, L.C.; AMRANTE, C.V.T.; SHIRAYAMA, D.; SCOLARO, A.M.T.; AYUB, R.A. Controle do escurecimento interno de ameixas durante o armazenamento pelo manejo do ponto de colheita e do etileno. Revista Brasileira de Fruticultura, Jaboticabal, v.33, n.2, p.376385, 2011.

BAILEY-SERRES, J.; FUKAO, T.; GIBBS, D.J.; HOLDSWORTH, M.J.; LEE, S.C.; LICAUSI, F.; PERATA, P.; VOESENEK, L.A.; VAN DONGEN, J.T. Making sense of low oxygen sensing. Trends in Plant Science, Amsterdam, v.17, n.3, p.129-138, 2012.

CORREAA, T.R.; STEFFENS, C.A.; TANAKA, H.; AMARANTE, C.V.T..; BRACKMANN, A.; ANESE, R.O. Manejo do etileno em ameixas 'Laetitia' armazenadas sob atmosferas controlada e modificada ativa. Revista Brasileira de Fruticultura, Jaboticabal, v.33, n.3, p.723729, 2011.

DALBÓ, M.A.; DELLA BRUNA, E.; BONIN, V. Ameixa. In: EPAGRI. Avaliação de cultivares para o estado de Santa Catarina - 2013-2014. Florianópolis: EPAGRI, 2013. p.10-13. (Boletim Técnico, 162).

FIORAVANÇO, J.C.; NACHTIGALL, G.R.; ANDOLFATO, W. Avaliação agronômica da ameixeira 'Letícia' em Vacaria, RS. Bento Gonçalves: EMBRAPA, 2015. p.1-8, (Circular Técnica, 122). 
FORNEY, C.F. Physiology and biochemistry of aroma and off-odors in fresh-cut products. Acta Horticulturae, Leuven, n.1141, p.35-46, 2016.

KHAN, A.S.; SINGH, Z. 1-Methylcyclopropene application and modified atmosphere packaging affect ethylene biosynthesis, fruit softening, and quality of 'Tegan Blue' Japanese plum during cold storage. Journal of Horticultural Science \& Biotechnology, Amsterdam, v.133, n.2, p.290-299, 2008

LUMPKIN, C.; FELLMAN, J.K.; RUDELL, D.R.; MATTHEIS, J. 'Scarlett Spur Red Delicious' apple volatile production accompanying physiological disorder development during low $\mathrm{pO}_{2}$ controlled atmosphere storage. Journal of Agricultural and Food Chemistry, Washington, v.62, n.7, p.1741-1754, 2014.

MINAS, I.S.; CRISOSTO, G.M.; HOLCROFT, D.; VASILAKAKIS, M.; CRISOSTO, C.H. Postharvest handling of plums (Prunus salicina Lindl.) at $10^{\circ} \mathrm{C}$ to save energy and preserve fruit quality using an innovative application system of 1-MCP. Postharvest Biology and Technology, Amsterdam, v.76, n.1, p.1-9, 2013.

NUNES, F.R.; STEFFESN, C.A.; HEINZEN, A.S.; SOETHE, C.; MOREIRA, M.A.; AMARANTE, C.V.T. Ethanol vapor treatment of 'Laetitia' plums stored under modified atmosphere. Revista Brasileira de Fruticultura, Jaboticabal, v.41, n.5, e-163, 2019.

ÖZKAYA, O.; YILDIRIM, D.; DUNDAR, Ö; TÜKEL, S.S. Effects of 1-methylcyclopropene (1-MCP) and modified atmosphere packaging on postharvest storage quality of nectarine fruit. Scientia Horticulturæ, Amsterdam, v.198, n.1, p.454-461, 2016.

SELCUK, N.; ERKAN, M. Changes in antioxidant activity and postharvest quality of sweet pomegranates cv. Hicrannar under modified atmosphere packaging. Postharvest Biology and Technology, Amsterdam, v.92, n.1, p.29-36, 2014.

SINGH, S.P.; SINGH, Z. Controlled and modified atmospheres influence chilling injury, fruit quality and antioxidative system of Japanese plums (Prunus salicina Lindell). International Journal of Food Science and Technology, Oxford, v.48, n.2, p.363- 374, 2013a.

SINGH, S.P.; SINGH, Z. Postharvest cold storage-induced oxidative stress in Japanese plums (Prunus salicina Lindl. cv. Amber Jewel) in relation to harvest maturity. Australian Journal of Crop Science, Lismore, v.7, n.3, p.391-400, 2013 b.
STANGER, M.C.; STEFFENS, C.A.; AMARANTE, C.V.T.; BRACKMANN, A; ANESE, R.O. Quality preservation of 'Laetitia' plums in active modified atmosphere storage. Revista Brasileira de Fruticultura, Jaboticabal, v.39, n.2, e-714, 2017.

STANGER, M.C.; STEFFENS, C.A.; AMARANTE, C.V.T.; CORRÊA, T.R.; TANAKA, H.. Qualidade póscolheita de ameixas 'Camila' e 'Laetitia' colhidas em diferentes estádio de maturação. Caatinga, Mossoró, v.27, n.2, p.214-221, 2014.

STEFFENS, C.A.; AMARANTE, C.V.T.; ALVES, E.O.; TANAKA, H.; BRACKMANN, A.; BOTH, V. Armazenamento de ameixas 'Laetitia' em atmosfera modificada. Ciência Rural, Santa Maria, v.39, n.9, p.2439-44, 2009.

STEFFENS, C.A.; AMARANTE, C.V.T.; ESPINDOLA, B.P.; HEINZEN, A.S.; BRACKMANN, A.; BOTH, V. 'Laetitia' plums stored in controlled atmospheres combined with induction of mass loss and ethylene management. Revista Caatinga, Mossoró, v.31, n.1, p.225-234, 2018.

STEFFENS, C.A.; TANAKA, H.; AMARANTE, C.V.T.; BRACMANN, A.; STANGER, M.C.; HENDGES, M.V. Condições de atmosfera controlada para armazenamento de ameixas 'Laetitia' tratadas com 1-metilciclopropeno. Revista Ciência Agronômica, Fortaleza, v.44, n.4, p.750756, 2013.

STEFFENS, C.A.; AMARANTE, C.V.T.; ALVES, E.O.; BRACKMANN, A. Fruit quality preservation of 'Laetitia' plums under controlled atmosphere storage. Annals of the Brazilian Academy of Sciences, Rio de Janeiro, v.86, n.1, p.485-494, 2014.

STEFFENS, C.A.; HEINZEN, A.; NUNES, F.R.; SOETHE, C.; AMARANTE, C.V.T.; BRACKMANN, A.; ARGENTA, L.C. Armazenamento de ameixas. In: ENCONTRO NACIONAL SOBRE FRUTICULTURA DE CLIMA TEMPERADO, 15., 2017, Fraiburgo. Anais [...]. Caçador: Epagri, 2017. v.1, p.111-115.

WRIGHT, A.H.; DELONG, J.M.; ARUL, J.; PRANGE, R.K. The trend toward lower oxygen levels during apple (Mallus $x$ domestica Borkh) storage - A review. Journal of Horticultural Science \& Biotechnology, Oxford, v.90, n.1, p.1-13, 2015. 